\title{
Myths and Realities about Language of Instruction in Pakistan: Parental Perspective
}

\author{
Habibullah Pathan \\ Mehran University of Engineering \& Technology, Jamshoro, Pakistan \\ Khalid Hussain Channa \\ Mehran University of Engineering \& Technology, Jamshoro, Pakistan \\ Shumaila Memon \\ University of Sindh, Jamshoro, Pakistan \\ Waqar Shah \\ Mehran University of Engineering \& Technology, Jamshoro, Pakistan
}

\begin{abstract}
Language of learning and language of state requires proper awareness in multilingual countries. It demands much clarity if the role of a language in learning is to be acknowledged on the academic achievement grounds. Language of instruction is a controversial issue in Pakistan. Language policies and practices play vital role in shaping the perceptions of individual for the choice of any language. These perceptions may be based on reality or merely myths. Parents are major beneficiary or sufferer of the outcome of the education of their children. This article aims to explore perceptions of parents for the choice of language for the education of their children. By drawing upon Woolard \& Schieffelin's Language Ideology Model (1994), this paper analyses how parents perceive the importance of language of instruction for the education of their children. The researchers conducted 20 semi structured interviews from parents of Hyderabad Town by using Maximum Variation Sampling. Constant Comparative Method (Lincoln \& Guba, 1985) of analysis is used as an analytic technique to discover perceptions of parents regarding language of instruction for the education their children. This research implies that perceptions of parents are fraught with myths and misunderstandings of past practices and unclear language policies in Pakistan. This study recommends that parents' voice must effectively be included in the making of language policy and they must be made aware of the researches in learning mother tongue or second language as the language of instruction for the education of their children.
\end{abstract}

Index Terms — medium of instruction, language policies in Pakistan, language ideology, bilingualism

\section{INTRODUCTION}

Pakistan is a multilingual country. There are 5 major and 61 other languages spoken here (Rahman, 1997). There is diversity in its cultural, social norms and values that ultimately affect to their approach and attitude towards education. Language policy, language corpora, and language status play vital role to deliver in the state where such complex and diverse ethnic groups of people live (Ammar et. all, 2015). Controversy is natural to erupt if language policy does not deliver to the spirit of people. The same happened in Pakistan when decisions about medium of instruction for the people with different linguistic and cultural background were made politically. Soon after the independence of Pakistan, the first education conference was held on $27^{\text {th }}$ November 1947 that made Urdu as a lingua franca of Pakistan and English as an official language. Medium of instruction for masses was Urdu or Vernacular language and English as a subject was from grade six onwards whereas there were English Medium private schools with quality education in which children of the elites would get education. This disparity was not at this level only but the controversy erupted soon after declaring Urdu as a national language in Pakistan and a compulsory subject to be taught. Urdu was already used in the Punjab, the N.W.F.P, and Baluchistan and in parts of Kashmir (Rahman, 1998). Sind and Bengal resisted the move. Bengal opposed Urdu as a national language and Bengali Language movement was started. Urdu-Bengali language controversy started. Advisory Board of Education set up Urdu Committee under the chairman ship of Abdul Haq, the father of Urdu (Baba-e-Urdu). The task of the committee was to encourage Urdu as a medium of instruction. The committee declared Urdu as medium of instruction in Punjab, N.W.F.P, Karachi and Baluchistan (areas administered by the Centre) (ABE, 1954).

Urdu and Islam was generally thought strongest pillar of unity for all groups but it did not worked in case of Bengal and Sindh. The state continued the so called idea of integration among all groups in the form "Urdu and Islam" through various language policies. Prominent leaders of Pakistan movement supported Urdu as national language. Muhammad Ali Jinnah (the first Governor General of Pakistan) said in his speech delivered in Bengal, “.... it is for you, the people of 
this province, to decide what shall be the language of your province. But let me make it very clear to you that the state language of Pakistan is going to be Urdu and no other language. Anyone who tries to mislead you is really the enemy of Pakistan" (Jinnah, 1948).

Rahman (1997) pointed that "Part of drive for creating a Pakistan- Muslim identity was the marginalization of the indigenous languages of Pakistan. Among these Bengal posed the greatest threat being the language of 54.per cent Pakistanis according to the consensus of 1951(Statement 4-B, p.71)." This shows that the decision for the medium of language was not taken on the basis of educational research and psychological needs of an individual but decision was made on the political grounds. Being new state Pakistan had many issues along with the issue of language. It continued to affect every educational plan and policy of Pakistan. Ayub Khan, the Commander-in-Chief and the military ruler set up a commission in 1959 to settle language issues. Sharif Commission stated that "Urdu and Bengali should be the medium of instruction in secondary schools (class 6 to matric) in the government schools" (Mahboob, 2002). There was no change in the policy of English medium schools and these were allowed to flourish. After Sharif Commission Urdu was made as medium of instruction in Baluchistan, NWFP, the Punjab but Sindh resisted and there were Sindhi-Mohajir clashes on the issue of languages. Sindhi was the medium of instruction before partition and Sindhis wanted to continue it instead of Urdu but Mohajirs wanted Urdu so there were mostly Urdu medium schools in the urban centres and Sindhi medium schools in the rest of Sindh.

Language issues continued in Pakistan. Nur Khan Commission (1969) also proposed that "the medium of instruction at all levels of education should be changed to Bengali in East and Urdu in West Pakistan" (PNEP 1969). But these decisions could not suffice to solve language issues which eventually signified "the divorce of East and West Pakistan" (Mahboob, 2002). East Pakistan became independent state as Bangladesh. However language issues in Pakistan were not taken seriously and the decision in New Constitution 1973 was made that "Clause 1 . The National Language of Pakistan is Urdu, and arrangements shall be made for its being used for official and other purposes within fifteen years from the commencing day. Clause2. Subject to clause (1) the English language may be used for official purposes until arrangements are made for its replacement by Urdu" (Article 251).

It was decided that English was to be replaced by Urdu within 15 years. Provinces were allowed to decide their language policy. However English was continued to be taught in schools. English medium schools were developed. In 1977, General Zia-al-Haq imposed martial law government in Pakistan and justified his coup through Islamization and Urduization policies. English medium schools of the state were shifted to either Urdu or to another recognized provincial language in each province. Private English medium of the elite kept growing but Urdu/vernacular medium schools began to prepare for complete Urduization of complete Urduization of exams by 1989. The government forced to use Urdu as a medium of instruction in the government schools but elite English medium schools continued to operate as usual. In the time of the governments of Benazir Bhutto and Nawaz Sharif from 1988 to 1999, English as a subject was started to be taught from grade one in all government schools and English medium schools grew in a great number. In 1999, it was decided to teach in English medium from grade one where teachers are available or teach English as a compulsory subject from grade one in all state owned Urdu/ Vernacular subjects. Education Sector Reforms (ESR) was initiated to work effectively. English medium education was encouraged and given preference in every walk of life so much so that mother tongues were given secondary or no preference at all. This created a major divide in the society.

Policies and practices have played major role in the mind set of common people when they see that English is being used in the civil administration and the bureacracy, in the legal and provincial system of fedral and provincial governments, in Defence Forces (Army, Air Force and Navy), in broadcast media and schools of elites so parents percieve medium of instruction for their children through socio-political and socio-economic perspectives of the use of the language. There has been common trend in Pakistan that parents mostly get their children admitted in English Medium Schools. They do so because they want their children proficient in English. It is considered essential vehicle for achieving modernization, scientific and technological development, and economic advancement for self and the country, in short, for improving one's life chances ( Haque,1982; Rahman, 1997; as cited in Channa, Memon, \& Bughio. 2016).

\section{Approaches to Language Ideology}

There are two main approaches to language ideology: neutral and critical. It is generally understood in neutral approach to language ideology that cultural system shapes the speakers ideas or assumptions for any language so no attempts are made to identify differences in the language because entire community or culture has common characteristic to shape language ideology; Whereas, critical approaches to language ideology seek the capacity for language to sustain social power and supremacy. Woolardand Scieffelin described as studies of "some aspects of representation and social cognition, with particular social origins or functional and formal characteristics." Critical approaches to language ideology are "reserved for only some aspects of representation and social cognition, with particular social origins or functional or formal characteristics (Woolard \& Scieffelin, 1994)."

Choice of any language to use or preference of any language in multilingual society is based on belief of people. Hence, parents perceptions can better be uncovered by drawing upon the theoretical framework of Woolardand Scieffelin (1994). Wie (2006) used critical approach to language ideology by Woolardand Scieffelin (1994) to discuss 
issue of language choice and ideology in multicultural Taiwan in her studies. I have also used critical approach to explore parental perceptions for the choice of language as medium of instruction in my studies.

\section{Theoretical Framework for the current research}

Drawing upon critical approach to language ideology by Woolard \& Schieffelin (1994) as a framework to my study, we shall explore the perception of people regarding any language. Attempts are made to uncover reasons for preference of any language since it is considered in critical approach to language ideology that preference or choice is related to language politics. Language has politically been used as a powerful tool to maintain power and supremacy by giving preference in every walk of life (Mahboob, 2012; Abbas, 1993).

\section{ReSEARCH METHOdOLOGY}

The aim of my inquiry was to explore the perceptions of parents about medium of instruction and understand their perceptions in the light of latest research about myths and realities of learning languages. It is a qualitative study because it "strives to understand and interpret the world in terms of its actors (Cohen, Manion, Morrison, 2007)".

It is a case study about perceptions of Sindhi Parents from Hyderabad whose children study in different schools and different grades in Hyderabad. The researchers have conducted 20 semi structured interviews from parents who were purposefully selected by applying maximum variation sampling technique (Seidman, 1998) in order to expand more variability.

The sample size generally agreed by researchers in qualitative studies is more or less 50 ( Bryman, 2015; Ritchie et al, 2003) but again, it depends on the point of saturation when additional data does not seem to develop the concepts any more, the same points are repeated that are already revealed (Glaser \& Strauss, 1967). Similarly I continued interviewing participants as long as I reached the point of saturation. I conducted 20 semi-structured interviews: 10 from male participants and 10 from female participants.

\section{DATA ANAlysis TeChNiQUE}

Constant comparative method (Maykut \& Morehouse, 1994) was used while analyzing the data. Constant comparative method involves inductive category coding and simultaneous comparing of units of meaning across categories. This technique of analysis is based on six stages. Firstly, unitizing the data which was done after transcribing all audio taped interviews with the help of Express Scribe Transcription software; Secondly, inductive category coding was made provisionally based on "look alike and feel alike criteria", Thirdly, categories were refined by making rules of inclusion as a propositional statements; Fourthly, exploration of relationship across categories were made in order to combine a few broader categories; Lastly the data was integrated in an attempt to uncover meaning.

\section{Perceptions of parents about medium of instruction}

a. Private schools are English medium schools and one who knows English is clever.

Findings reveal that most of the parents (100\%) seemed to have taken for granted that private schools mean English medium schools. The parents considered English medium schools to those schools where almost all subjects are in English. However, these subjects are explained in Mother tongue for the better comprehension of the students. Most of the parents acknowledged that the communication between teacher to student and teacher to teacher is mostly in the mother tongue. Only books are in English.

"They teach in English but explain in Sindhi so the children could understand properly." IF1.

Some of the parents are of the view that it is good to translate English into local language and it is better method for understanding.

"See, we recite the Holy Quran. We cannot understand the meaning of a verse unless we translate it into Sindhi. Similarly, if we read anything in English, it would be better if we translate it in our mother for our understanding." IF 5.

Some of the parents considered getting admission in private schools means insurance of quality education. They assumed that their children are getting standard education because they study in English medium schools where their children are taught English books and their children learn English so he is clever.

b. English medium education is gate way to success

All of the parents considered education as determining factor for the future of their children. They thought that education of their children in English medium school would provide them better chance to go abroad. English is considered like a passport and a gate way to the world; and mother tongue would not play as much important role as English does.

"English has importance and if the children go out of the country there they need English."

\section{Interviewee Female 2}

Parents supported English medium education because it would help their children to pursue higher education successfully. Parents want their children to excel at English so they admit them in English medium school. Parents considered it pre requisite to pass any admission test for higher studies without efficiency in English.

"Yes, it is very much related. English has great importance. We are also attached emotionally with Sindhi. We wish to develop it. However English is compulsory for job and business in the world. As world is a global village and our child has to live in this global village successfully." IM2 


\section{c. Education in English Medium Schools as matter of prestige and status}

Parents $(55 \%)$ acknowledged that one of the major reasons to enroll their children in famous English medium schools is to show that they are from high status family. Parents mostly ask one another when they meet in the gatherings about education of their children. It is generally assumed that educating in well reputed English medium schools give their children a high esteem and standing in the society.

"Another phenomenon has been observed in the masses that they compete with their relative in the sphere of social strata. As our society is divided into classes similarly our education system is also divided and we usually admit our children according to our status in society." IM 6

\section{d. Education in English Medium Schools and learning}

Some of the participants supported that English as a medium of instruction enhances the learning of the child. Parents added that studying in English medium schools does not create problems for children if parents and teachers work together. The children can easily solve their problems which they encounter while learning English language. They can fully express their anxieties with their teacher and with their fellows in classroom. Thus, the language plays a vital role towards learning. English language minimizes the communication gap between a teacher and the students.

"These private schools are good at giving English speaking environment in classes. The teachers teach them to talk and how to pronounce words and how to behave in a particular way. More focus is given to their body language while speaking English language. The children don't feel any difficulty while listening to English language.” IM5

However, some parents did acknowledge that their children feel great difficulty in learning and understanding the concepts being taught at the school. They confirmed that their children can hardly express what they want in English language. It is therefore teachers also use translation method for better understanding of students.

"Language is a barrier. For example, I am getting education in China and I don't know Chinese when the lecture is continued in class in Chinese, it is a barrier in learning. Language prepares a ground for understanding the speaker and the listener. Language is a barrier if a language of learner is not continued in the class or anywhere, how can learning get across. It is a barrier, no doubt, if the listener does not understand. Language is a barrier if it is out of the context of class. I speak English language, if the listener does not understand, then no doubt the language would be a barrier. It is a barrier if language is spoken which is not the language of the listener." IM5

"Medium of instruction is undoubtedly related to the outcome of better learning. Mother tongue has the magic to attract the child as compare to other tongue. He understands many things when is ready to go to school. So a child is developed mentally through mother tongue but when child goes to school, he is taught through other tongue which is totally new and difficult for him. It leaves an impact on the learning of a child and the mental capacity of a child. The child cannot perceive learning at any cost. IM6

\section{e. Education in Mother tongue helps better comprehension}

Parents $(85 \%)$ perceived mother tongue as a great resource. Teaching in mother tongue fades away ambiguous concepts in learning. Child gives better feedback in the early years of education.

"Sindhi (first tongue) plays key role in the early life and child easily understands the essence of the message" IM2

"The child faces problems. Because we the parents do not assess their child's learning properly. Otherwise it is clear that if we begin studies in mother tongue, it becomes easier to understand the concepts and interpret the ideas of learning'IM3

\section{f. Education in Mother tongue develops creativity}

If the language one thinks and the language one speaks is the same, one generates and expresses one's feelings or point of view easily. Creativity occurs when there is no barrier as such of language to express. The cognitive process of the child develops the analytic faculty to speak as he feels. So learning in one's mother tongue enables the child to grasp quickly the essence of things being taught and reproduce it with his own acumen.

\section{g. Education in Mother tongue integrates home and school experiences}

One interviewee was of the opinion that there should be integration of experiences children have at home with learning at school. If experiences at school do not bridge or coordinate with the environment out of school then, the children will face complexities and cognitive imbalance. So mother tongue plays vital role to supplement home experiences with learning at school.

"If the language being taught with is mother tongue then the children can easily share feelings, experiences and learning with their parents, they can express in mother tongue. Thus the mother tongue plays an important role in learning. So it is very important. Even we also easily share our experiences in mother tongue." IM3

\section{h. Education in Mother tongue and English}

Some of the interviewees responded that the mother tongue should be taught from primary level as it provides many opportunities in learning the things more effectively. It creates a sort of platform where the child can express his feelings, miseries, emotions, and difficulties more conveniently. Many parents forwarded the idea that the mother tongue should be taught to the child in the primary classes because it is the age when child easily develops cognitive processes. Moreover, some of the participants were of the opinion that learning many languages in early years of school is a very good sign because it develops the critical thinking of the children.

"I think that there is no harm if the child is taught in Sindhi as a medium of instruction till class five and then he carries his education in English. Ultimately, everybody perceives the future of their children in English language." IM3 


\section{DISCUSSION}

The findings suggest that parents have quite positive inclination towards English as medium of instruction. In fact, most of the parents considered English as a success ladder which has been used by a small and power elite section of society since long in order to grab high positions. English has acquired a very significant symbolic value in Pakistan (Shamim, 2011) so much so that it is considered equal to quality education. There is common perception that English makes man clever. However, English is a language and cleverness is related to knowledge. It is a myth and it is quite misunderstanding of parents who consider their children clever or wise when they speak English. Most of the parents are not clear in Pakistan about how children learn languages and about the role of language in education (Coleman \&Capstick, 2012). Parents' perceptions are based upon the long gap between policies and practices in Pakistan. When they see that government schools lack basic facilities and unable to deliver quality education as compared to private schools, they make an effort to safeguard the future of their children by educating them in English medium schools. It is however misleading that parents perceive English equal to quality education because most of the private schools are in English and these give better results. In fact, there is casual relationship between English and higher achievement (Coleman \&Capstick, 2012). In fact, other factors like curriculum, teachers' qualification, and facilities and management at school, examination system, resources, and background of parents, motivation of children contribute to higher results. English medium education in the early years does not guarantee quality education but makes learning more rigorous and confusing for children in multilingual settings (Coleman \&Capstick, 2012). Had there been schools with similar resources with credible names teaching mother tongue as medium of instruction for the early years of education, one would have then seen the preference of parents for Straight to English as medium of instruction.

Findings suggest that most of the parents perceived that learning in English at an earlier age help children learn well and it will help their children in the long run. Parents consider it advantageous but it is mostly myth and misunderstanding keeping our context in Pakistan where English is a foreign language in the most areas and second language in a few big cities only. English, no doubt, helps in the long run because it is the language of market and economy; education and technology; research and globalization, but teaching in English medium at an earlier stage is not supported by most of the researchers (Coleman \&Capstick, 2012; Cummins \&Horberger, 2007; Mohanty, 2006). English is our second language. It can better be learnt after learning our first language (mother tongue) (Cummins \& Horberger, 2007; Mohanlal, 2001; Muthwii, 2004; UNESCO Report, 2016). "Policies of going 'straight to English' are likely to be counterproductive. Children need to be skilled and confident speakers of their first language and able to read and write in their first language before starting to learn a second language in a school context; omitting the stages of achieving oracy and literacy in the first language actually handicaps children in the learning of the second language (Coleman \& Capstick, 2012 )" which eventually tends to rot learning. This is a usual phenomenon told by parents that their children remember things in order to get marks in exam but they do not comprehend those things. Learning science and mathematics in English at the earlier stage of education of children creates problems because these subjects need that type of English when Children are able to process cognitively comparing, contrasting, classifying, defining, and hypothesizing. They will also need the English language skills of predicting, skimming and scanning in reading; of planning, drafting and editing in writing; of predicting and evaluating when listening; and of setting goals, expressing opinions, evaluating outcomes and reporting back in speaking. Researches confirm that it takes two years to learn social English but seven years to acquire education English (Clegg, 2007, Cummins, 1996). And in Pakistani context, it may even take more time hence English medium education drag children to remember things word by word. Children in English medium find themselves in a deep well which denies them right of looking world out of that specified well. As a result, most of the children cram in order to pass in the examinations. UNO (1951) confirms that it is born right of child to learn in the mother tongue.

Findings suggest that most of the parents are unaware of negative consequences if their children are not taught in the mother tongue in the early years of education. Subtractive bilingualism is when one leaves one's mother tongue and start education with second language."Subtractive dominant - language medium education for IM [indigenous and minority] children can have harmful consequences socially, psychologically, economically and politically. It can cause very serious mental harm: social dislocation, psychological, cognitive, linguistic, and educational harm, as well as economic, social, and political marginalization (Skutnabb - Kangas 2009:340)." It also confirms my findings when a few of the parents admitted that their children do not understand context of the learning because it is not in mother tongue so children lack analysing things being taught at school and they are unable to reflect their learning experiences freely.

Learning in English medium limits children to share their learning experiences whereas mother tongue education in the early years gets support from home. Parents help is pre requisite for achieving required results in the education of children. They can better be involved in the education process of children if the language of school and home is the same. The first language of the parents in Sindh is not English. Moreover, researches that recommend mother tongue education as medium of instruction in the early years of education further confirm this view of some my potential participants in the research that learning is enjoyable when it is acquired through a language with which children are already familiar; The basic conceptual development is more effective because children actively involves in learning by exploring and questioning if it is their home language (Coleman \& Capstick, 2012). Therefore "perceptions of parents though a few of them, confirms that learning in mother tongue enables their children better comprehension, develops 
creativity, bridges experiences at home with learning at school, and enhances the vocabulary to express freely"(Channa, Memon, \& Bughio, 2016).

Findings support the perpetuation of mindset from centuries when it comes to the sky high line between the superiors and inferiors and role of English language works like parameter for making that line in all British colonies of the world. Pakistan is not the exception to this phenomenon where people consider English a pre-requisite for gaining and maintaining their status in the society. Most of the parents viewed that it was incumbent to enrol their children in well reputed English medium school. Their perceptions may be justified in the context of Pakistan where languages are politicized in order to acquire underlying purposes or to survive themselves politically. There is a lack of understanding on the part of parents for the efficacy of language of education in the early years of children. Parents prefer English medium schooling in order to shorten their self-perceived the colossal dividing line between regional and international; modern and ancient; latest or old; higher and lower; special and common type of education. This happens when there is no clear concept of learning and lack of one system of education in the country. Government policies, plans, commissions have not been effectively able to diminish this dividing line between "have" and "have not" perception of parents related to the education of their children.

Parents are confused and indecisive when they see various educational systems being operated at a time around them. Issue of medium of instruction becomes more complex when government higher secondary schools stand in contrast with Cambridge system of education; Madressahs stand against English medium schools; government schools provide different education than private schools; and low status schools differ from elite private schools. Findings as has been discussed in Channa, Memon, \& Bughio (2016) show that some parents viewed English language as a barrier for the speakers of second language. They admitted that English hampers creativity and their children could not express their ideas freely in English but they wanted their children study in English medium school. Parents viewed it necessary to go with the world and maintain their status in the society. They held that difficulties in learning in English medium school, faced by their children initially, would be recovered with the space of time and their children would have better academic history. They would have an edge over others in every walk of life because of being educated in English medium school. Findings to my research question about preference of medium of instruction show that almost all parents prefer English medium education however some of them agreed that mother tongue should be taught as a subject for a few years. Parents perceived the role of mother tongue was very limited and it could be achieved in the home or from society. They considered it secondary to learn mother tongue. Their top priority was that their children should be well versed in English therefore they usually made efforts to communicate their children in English even if most of the parents did not know it properly. They tend to code switching.

Parents complained that most of the private schools did not have mother tongue as a subject. Even if there is mother tongue subject in private schools, it is relegated to teaching mother tongue to the so-called record filling formality. This shows result of the parents' preference and priority on the one hand and indifferent attitude of private schools toward teaching mother tongue on the other hand. They give prime importance to English instead of learning itself. This happens when state fails to deliver status to native language.

Findings in my research show that some parents complained that their children were unwilling to write in Sindhi or Urdu because they were taught in English medium schools. Parents found their children almost difficult to count numbers in the mother tongue. 91.62\% of the population of Pakistan speaks mother tongues that are not used as language of instruction (Pinnock, 2009). Rahman and Shamim have argued that 'linguistic apartheid' has led to the creation of exclusive English - medium zones within the education system and that these exacerbate social division. This is alarming situation and most of the parents felt embarrassed to share that their children did not know how to count or write in mother tongue but they were ready to go with English in order to maintain status by proudly mentioning the name of English medium school of their children. Parents devalue mother tongue when it comes to be the medium of instruction so their children find it boring or extra burden to learn mother tongue in the schools. The results of researches found it otherwise "children find learning a second language in a school context easier if they have positive feelings about both their home language and the language which they are learning. But their learning of the target language is likely to be less productive if they have a negative attitude towards their own language or if they feel that their home language is of low status compared to the language which they are hoping to learn (Colmen\&Capstick, 2012)".

Findings show that most of the parents preferred to provide their children education on the pattern of western education system which is found in English medium schools. They thought that their children would get exposure of international culture which would ultimately benefit them in this period of globalization. This rhetoric of English for globalization is ubiquitous (Colmen \& Capstick, 2012) and when it comes to Pakistani context, it is "too powerful (Shamim, 2011)". There is no doubt English plays gate keeping role but it affects adversely if one disowns one's mother tongue and one's identity (Cummins, 2000). Globalization accepts diversity and one's footing and foundation should be mother tongue if one finds their children fly with their own respective identity. Early education in mother tongue gives their children sense of identity which validates and strengthens to accumulate the rest of languages and work successfully for globalization (Colmen \& Capstick, 2012). However, Most of the parents had perception that syllabi, atmosphere, and grooming of their children were but some of the factors which they thought would support their children in the long run and they perceived that these were better found in English medium schools. Mustafa (2012) 
looks the language situation in this way. "Such is the power of myths about language in Pakistan that a public demand has been created for English. People believe that English is the magic wand that can open the door to prosperity. Policymakers, the wielders of economic power and the social elites have also perpetuated this myth to their own advantage. The door of prosperity has been opened but only for a small elite".

Another common perception of almost every parents as shown in finding 2, reinforced in the researches of Mehboob (2002), Rahman (1997, 2004), Shamim (2008), Evans \& Cleghorn (2014), Muthwii (2004) and E.O.S Lyamu and S.E.A. Ogiegbaen (2007) as has been cited in Channa, Memon, \& Bughio (2016) that education in English medium schools is the determining factor for the career of child in case of going for abroad, for pursuit of higher education and for getting good job or success in business. English is undoubtedly a pre-requisite to get a good job in Pakistan because every examination is in English. Mostly interview is taken in English for job. It is necessary to be good at English if one wishes to get higher education because most of the books are in English and most of the latest researches are in English. Not only this but one has also to qualify different tests for higher education. English works like passport to go abroad. It is almost difficult to do a successful business without knowing English not only in most of the countries of the world but in Pakistan too because most of the communication or paper work is being done in English. It has now become an admitted fact that the accomplishment of people's dreams are more or less attached with the knowledge of English and become from the dominant groups but to attach it with early medium of instruction is a blind or misleading race which may culminate at the great loss of one's mother tongue and one's identity. In this way, different generation with complex culture would come and replace the language with norms and values in the society. It is nothing less than linguistic genocide. There are a number of researches that confirm these misperceptions of parents in the multilingual settings. This is however clear that a great confusion exists when it comes to the choice of language for the education of children because it is generally stemmed out of general perceptions and goals that they attach with their children's future (Evans \& Cleghorn, 2014). There is a great need to aware parents about how second language is learnt better and what is importance of the first language (mother tongue).

Pointing to a very similar finding in Evan \& Cleghorn's (2014) where 95\% parents chose English as the primary medium of instruction instead of mother tongue. The findings reinforce that $85 \%$ parents chose English as the primary medium of instruction in Sindh, Pakistan. Only three out of twenty parents said that education in mother tongue in the early years of education support English in the later years. They gave example of renowned personalities like Allama I. I. Kazi\& A K Brohi and others whose education was in mother tongue and they excelled at English as well. Parents perceived that mother tongue education was effective in helping the child to understand environment around him. Teaching mother tongue as medium of instruction in the early years of education is in line with E.O.S Lyamu and S.E.A Ogiegbaen (2007) Evans \& Cleghorn (2014), Cummins (2007), Milton (2005), Mohanlal (2001), and other researches that support additive bilingualism.

Most of the parents' attitudes towards language of instruction, in the early years of education stand in contrast to current research in the field of second language and bilingual education. It advocates development of home language in school along with full access to English but pitiably additive approach to multilingualism has not been fully implemented in Sindh because political will is lacking to counter the hegemony of English in the early education of children.

\section{CONCLUSION}

Parental perceptions about medium of instruction are affected due to their aspirations for their children's' future in the society as they observe and experience the top priority for English. Most of the parents inadvertently wish to be and follow rich and elite class that prefers English medium school for their children in order to achieve similar status and privilege in the society. But in fact it is an illusion. It is a paradoxical situation which stands against research in learning second language.

Critically drawing upon the framework of language Ideology by Woolard \& Schieffeln (1994), I conclude that parents' perceptions regarding medium of instruction are manipulated and speculative. The reasons are however; symbolic and pretentious. Parents prioritize for straight -to- English policy because they are pushed by their myth type perceptions that if their children learn through mother tongue in the early years of education, they will not learn better English later; Straight - to- English medium policy has advantage and no negative effects in the education; English makes man wise and clever and mother tongue education has no importance; English should be medium of instruction because of globalization; Private schools give quality education and they teach in English medium but these and other such type of myths are nothing but misunderstandings and misperceptions. It is evident that most of the parents relegate mother tongue as the medium of instruction. It indicates the parents' lack of awareness about the process of learning a second language. However, these perceptions are in fact, outcome of wrong practices and imprudent policies in Pakistan. Their embedded perceptions are necessarily to be addressed in the line of research in the field of learning a second language. Parents' awareness is pre requisite for implementation of additive bilingual education in its true sense.

The study recommends that parents should be involved in the policy making process since they are the major beneficiary and sufferer for the outcome the education of their children. Without parents' cooperation, educational policies and targets cannot be achieved so parents' awareness sessions and seminars must be held at the grass root level. 
Parents' myths and misunderstanding must be removed with solid proofs if successful implementation of educational plans is needed.

Bilingual education system should be introduced and smooth transition from first language (mother tongue) to second language (official language) should be schemed out. This needs a political will and commitment to involve all stake holders and provide required resources. Parents must be informed the importance of mother tongue for learning second language. Language status to mother tongues in Pakistan should be reviewed and addressed as per the latest research and status in the world around. Language policy should recognize the importance of mother tongue and give it due status in Pakistan.

Bilingual education is the panacea for all myths and misunderstandings in the society for learning a second language. Both curriculum and curriculum implementers play vital role in the successful results of bilingual education so it will give fruits if teachers are trained to understand bilingual education and teach accordingly. Curriculum should be schemed keeping cultural and social diversity of the people.

\section{REFERENCES}

[1] Abbas, A. (1993). The Power of English in Pakistan. World Englishes 12(2), 147-156.

[2] ASER. (2012). Annual Status of Education Report Islamabad Pakistan: ASER Pakistan.

[3] Bryman, A. (2016). Social research method: Oxford university press. U.K. ISBN:9780199689453.

[4] Channa, Memon, \& Bughio. (2016). English Medium or No English Medium: Parental Perspectives from Pakistan. Theory and Practice in Language Studies. Vol. 6, No. 8, pp. 1572-1577.

[5] Clegg, J. (2007). Moving towards bilingual education in Africa. In H. Coleman (Ed.), Language and development: Africa and Beyond (pp. 49-64). Addis Ababa, Ethiopia: British Council.

[6] Cohen, L., Manion, L., \& Morrison, K. (2000). Research Methods in Education [5 thedn] London: Routledge Falmer. Teaching in Higher Education, 41.

[7] Coleman.H., \&Capstick, T. (2012). Language in education in Pakistan: Recommendations for policy and practice. Islamabad: British Council

[8] Cummins, J. (2000). Language, power, and pedagogy: Bilingual children in the crossfire. Clevedon: Multilingual Matters

[9] Cummins \& Hornberger, N. (eds.). (2007). Encyclopaedia of language and education ( $\left.2^{\text {nd }} e d\right)$. New York: Springer.

[10] Evans, R., \& Cleghorn, A. (2014). Parental perceptions: a case study of school choice amidst language waves. South African Journal of Education, 34(2), 01-19.

[11] Glaser, B. G., \& Strauss, A. L. (2009). The discovery of grounded theory: Strategies for qualitative research. Transaction Publishers. New Burnswick. U.S.A.

[12] Haque, A. (1993). The position and status of English in Pakistan. In Baumgardner, R. (ed.) (1993). The English Language in Pakistan. Karachi: Oxford University Press.

[13] Iyamu, E. O., \& Ogiegbaen, S. E. A. (2007). Parents and teachers' perceptions of mother-tongue medium of instruction policy in Nigerian primary schools. Language, culture and curriculum, 20(2), 97-108.

[14] Jinnah, M. (1948). Speech at a public meeting at Dacca, 21 March. In Quaid-I-Azam Mohammad Ali Jinnah: Speeches and Statements 1947-8. Islamabad: Government of Pakistan, Ministry of Information and Broadcasting, 1989.

[15] Laforest, J., Bouchard, L. M., \& Maurice, P. (2012). Guide to Organizing Semi-structured Interviews with Key Informants: Safety Diagnosis Tool Kit for Local Communities. Institut national de santé publique Québec avec la collaboration de Ministère de la sécuritépublique.

[16] Lincoln, Y. S., \& Guba, E. G. (1985). Naturalistic inquiry (Vol. 75). Sage Publishing India

[17] Maykut, P. S., \&Morehouse, R. E. (1994). Beginning qualitative research: A philosophic and practical guide (Vol. 6). Psychology Press London

[18] Mahboob, A. (2002). No English, no future: Language policy in Pakistan. In S. O. B. Hartford (Ed.), Political independence with linguistic servitude: The politics about languages in the developing world. New York: NOVA Science

[19] Milton, R. (2006). The context of learning. Schooling

[20] Mohanlal, S. (2001) Mother-tongue education and psycho-societal involvement in tribal communities; A case study of Paniyi tribe. Language in India 1 (3), 1-9.

[21] Mohanty, A. K. (2006). Multilingualism of the unequals and predicaments of education in India: Mother tongue or other tongue? In O. Garcia, T. Skutnaab-Kangas \& M. E. Torres-Guzman (Eds.), Imagining Multilingual Schools: Languages in Education and Glocalization (pp. 262-283). Clevedon: Multilingual Matters.

[22] Muthwii, M. J. (2004). Language of instruction: A qualitative analysis of the perceptions of parents, pupils and teachers among the Kalenjin in Kenya. Language Culture and Curriculum, 17(1), 15-32.

[23] Mustafa, Z. (2012) Pakistan ruined by language myth. The Guardian. http://www.guardian.co.uk/education/.Retrieved on 21. 12. 2016.

[24] Pinnock, H. (2009). Language and education: The missing link, the language used in schools threatens the achievement of Education for All. UK: Save the Children

[25] Rahman, T. (1997). The medium of instruction controversy in Pakistan. Journal of Multilingual and Multicultural Development, $18(2), 145-154$.

[26] Rahman, T. (2002). Language and Politics in Pakistan Karachi: Oxford University Press.

[27] Rahman, T. (2004, January). Language policy and localization in Pakistan: proposal for a paradigmatic shift. In SCALLA Conference on Computational Linguistics (Vol. 99, p. 100).

[28] Seidman, I. (1998). Interviewing as qualitative research. New York: Teachers College Press.

[29] Shamim, F. (2008). Trends, issues, and challenges in English language education in Pakistan. Asia Pacific Journal of Education, 28(3), 235-249. 
[30] Skutnabb-Kangas, T. (1984). Bilingualism or not: Education of minorities. Clevedon: Multilingual matters.

[31] UNESCO. (2016). Global Education Monitoring Report. Policy paper 24.

[32] Wei. J. M. (2006). Language Choice and Ideology in Multilingual Taiwan. Language and Linguistics..7.1:87 -107, 2006-0-007001-000050-1

[33] Woolard. A. A \&Schieffelin. B. B. (1994). Language Ideology. Annual Reviews. www.annualreviews.org/aroline Retrieved on 15.11.2016.

Habibullah Pathan is Director and Associate Professor at the Directorate of English Language \& Development Centre of Mehran University Pakistan. He did first Master's from Pakistan, followed by his second professional Master's in ELT from University of Glasgow, UK in 2009. Dr Pathan then completed his PhD at the University of Glasgow, UK in 2012. His research investigated the socio-psychological factors specifically (motivation and change) of learning a second Language. Later, under Fulbright fellowship he did his postdoctoral research at MIT, USA under supervision of Prof Chomsky and completed his project on 'Indoctrination through State controlled textbooks in Pakistan'. In addition, Dr Pathan completed his Hubert H Humphrey fellowship at Boston University USA in fields of Higher Education Administration, Policy and Planning and also received certifications from (1) State department signed by US President Obama and Senator John Kerry and (2) certification from Questrom Business school in non profit management and leadership. Dr Pathan has to his credit more than 18 research papers published in International Journals majority of which are indexed with ISI master list of Thompson Reuters USA. He has also presented his research papers on L2 motivation in International conferences as keynote speaker. At Harvard University Social Enterprise Conference 2016, Dr Pathan was member of 5 member team who won 'Hackathon' on team's proposal for improvement of community colleges in USA. Dr Pathan also presented his paper on financial literacy and financial inclusion in Pakistan at Boston University, Higher Education Reforms in Pakistan at University of California Davis and a group presentation at Global Leadership Forum at Washington DC on 'Green Financing'.

Khalid Channa has done MS from English Language \& Development Centre of Mehran University Pakistan. He works as Lecturer at Government Degree College Sehwan, Sindh. He has done Masters in Education and English Literature. He serves as Secretary Education to Sindh Graduates Association. He is member of Board of Governors to Public School Gadap Karachi and Roshan Tara Higher Secondary School Ghotki.

Shumaila Memon is a PhD in Linguistics from Centre for Research in English Language Learning and Assessment, University of Bedfordshire, UK. Her major fields of interest are second language learning, attitudes towards languages, reading attitudes in second language and assessment of reading proficiency in English. Currently, she serves as Associate Professor at the Institute of English Language and Literature, University of Sindh, Jamshoro. Dr Memon is representative of Sindh Chapter of Linguistic Association of Pakistan. She is also editor of Ariel, International Research Journal of English Language and Literature. Besides, she reviews for many reputed journals at national and International level.

Waqar Shah has done MS from English Language \& Development Centre of Mehran University Pakistan. He serves as lecturer at English Language \& Development Centre of Mehran University Pakistan. 